\title{
Nerve Cell Survival
}

National Cancer Institute

\section{Source}

National Cancer Institute. Nerve Cell Survival. NCI Thesaurus. Code C25983.

Processes that promote, sustain, and preserve nerve cell viability. ( $\mathrm{NCl})$ 